\title{
The Transnational Histories of Southern African Liberation Movements: An Introduction 1
}

Jocelyn Alexander (University of Oxford), JoAnn McGregor (University of Sussex) and Blessing-Miles Tendi (University of Oxford).

This volume offers new transnational perspectives on southern Africa's wars of national liberation. It does so by bringing fresh evidence to bear on the histories of Zimbabwean, Namibian, Mozambican and Angolan liberation movements, allowing us to build on the insights of an extensive body of work on the South African ANC in exile and a growing literature on the 'global' Cold War. ${ }^{2}$ In keeping with much of this work, our contributors have assumed neither the primacy (or homogeneity) of nationalist loyalties as they exist within the boundaries of today's nation-states, nor any straightforward imposition or transfer of Cold War ideologies or strategic interests onto southern African conflicts. The articles instead follow the movement of ideas, people, institutions and goods across borders. Their primary focus is on African soldiers, politicians and diplomats, people whose relationships and motivations were varied and shifting, and whose interactions created opportunities for the circulation, promotion, and adaptation of a great range of cultural, political and military influences. Tracing these interactions within and among liberation movements, their hosts, and a wider set of external actors, reveals lasting and sometimes surprising - legacies that have too often been eclipsed by dominant national histories.

In approaching histories of Southern African militaries and political actors in this mode, the volume builds on a rich body of recent scholarship that has called for a transnational lens on Southern African struggle history. In an important collection, Hilary Sapire and Chris Saunders argue that 'liberation movements and international solidarity' should be discussed in a single frame, and have sought to integrate previously discrete bodies of research on 'internal' and 'external' dimensions of struggle. ${ }^{3}$ Luise White and Miles

\footnotetext{
${ }^{1}$ Almost all of the articles in this volume were first presented at the Journal of Southern African Studies' First Biennial Conference on Southern Africa Beyond the West, held in Livingstone, Zambia, in August 2015. The discussions that took place in that venue were vital to developing the ideas represented here. ${ }^{2}$ Writing about liberation movements inevitably involves a forest of acronyms. We consolidate those cited herein in this note to avoid constant disruption of the text. The armed wing of the South African ANC (African National Congress) is uMkhonto weSizwe (MK). Zimbabwe's liberation movements are the Zimbabwe African People's Union (ZAPU) and its armed wing the Zimbabwe People's Revolutionary Army (ZIPRA), and the Zimbabwe African National Union (ZANU) and its armed wing ZANLA (the Zimbabwe African National Liberation Army). After independence in 1980, ZANU became ZANU(PF), the PF referring to the Patriotic Front. In Mozambique, FRELIMO is the Frente de Libertacao de Mocambique. In Namibia, SWAPO is the South West African People's Organisation. The Apartheid state's forces that fought against SWAPO are SWATF (the South West African Territorial Force) and Koevoet (crowbar), a police counterinsurgency unit. In Angola, the MPLA is the Movimento Popular de Libertacao de Angola, and UNITA is the Uniao Nacional para a Independencia Total de Angola.

${ }^{3} \mathrm{H}$. Sapire and C. Saunders (eds), Liberation Struggles in Southern Africa in Context: New Local, Regional and Global Perspectives (Claremont, UCT Press, 2013), p. 7. Also see H. Sapire, 'Liberation Movements,
} 
Larmer 'coin the term "un-national" to underscore how much of national liberation took place in and between spaces that were categorically different from the national frame'. ${ }^{4}$ They note just how 'many players were motivated by - among other things - broader ideological notions of change, ethno-regional allegiances, personal advancement and access to education', motivations obscured by an assumed 'single, one-way journey from tyranny to national liberation'. ${ }^{5}$ Scholars have developed these points in studies of the turbulent relationships within the frontline states that hosted liberation movements. The chaotic and at times repressive governance of military camps and the disparate lives of exiled communities in cities and towns reveal the making of particular kinds of political relations as well as new social and cultural worlds in these distant places. ${ }^{6}$ Work on Cold War history has also contributed to fresh interpretations of transnational relations by offering a 'decentred' and 'globalised' perspective that goes well beyond East versus West binaries, notably revisiting and revising histories of nationalism and modernity. ${ }^{7}$

The aim of authors in this volume is not to reject the importance of nationalism or indeed global ideologies per se, but rather to set them among other drivers of mobility, war and movement history, and to trace the ways in which ideas and practices actually circulated across time and space. This is an extraordinarily complex task. Each of the countries we focus on had multiple, usually antagonistic movements that fought for recognition and support from African states, Cold War powers, and supranational

Exile and International Solidarity: An Introduction', Journal of Southern African Studies, 35, 2 (2009), pp. 271-86.

${ }^{4}$ L. White and M. Larmer, 'Introduction: Mobile soldiers and Un-national Liberation of Southern Africa', Journal of Southern African Studies, 40, 6 (2014), pp. 1271-74.

5 White and Larmer, 'Introduction', p. 1271.

${ }^{6}$ A major contribution on camps is C. Williams, National Liberation in Post-Colonial Southern Africa: A Historical Ethnography of SWAPO's Exile Camps (Cambridge, Cambridge University Press, 2015). For different approaches, related to the ANC, see S. Ellis, 'Mbokodo: Security in ANC Camps, 1961-1990', African Affairs, 93, 371 (1994), pp. 279-98, and S. Davis, 'Training and Deployment at Novo Catengue and the Diaries of Jack Simons, 1977-1979', Journal of Southern African Studies, 40, 6 (2014), pp. 1325-42. The work on the ANC in exile has broken new ground in many other areas too. In a large literature, see the important work of M. Suriano and A. Lissoni, 'Married to the ANC: Tanzanian Women's Entanglement in South Africa's Liberation Struggle', Journal of Southern African Studies, 40, 1 (2014), pp. 129-50; C. Tsampiras, 'Sex in a Time of Exile: An Examination of Sexual Health, AIDS, Gender and the ANC, 19801990', South African Historical Journal, 64, 3 (2012), pp. 637-63; R. Sandwell, "Love I Cannot Begin to Explain": The Politics of Reproduction in the ANC in Exile, 1976-1990', Journal of Southern African Studies, 41, 1 (2015), pp. 63-81; S. Hassim, 'Nationalism, Feminism and Autonomy: The ANC in Exile and the Question of Women', Journal of Southern African Studies, 30, 3 (2004), pp. 433-55; M. Armstrong, 'Healthcare in Exile: ANC Health Policy and Health Care provision in MK Camps, 1964 to 1989', South African Historical Journal, 6, 2, 2014, pp. 270-90; S. Morrow, B. Maaba, and L. Pulumani, Education in Exile: SOMAFCO, the ANC School in Tanzania, 1978-1992 (Cape Town, HSRC Press, 2004). Much of this work relates to Tanzania. A related body of literature focuses on Dar es Salaam's role as a cosmopolitan hub for political movements and as a 'Cold War city'. See G. Roberts, 'Politics, Decolonisation and the Cold War in Dar es Salaam, c. 1965-72’ (PhD, University of Warwick, 2016).

7 The work of O. A. Westad, The Global Cold War: Third World Interventions and the Making of our Times (Cambridge, Cambridge University Press, 2005), is seminal in this regard. The questions raised by Westad have sparked growing debates among scholars of particular regions, not least over the balance of influence among actors and ideas from the 'East', 'West' and 'South'. See for example the special issue of the International Journal of Middle East Studies, 43, 2 (2011), devoted to 'Relocating Arab Nationalism'. 
organs such as the Organization of African Unity (OAU). Some had rival liberation armies, hosted and supported by different backers, who were themselves competitors for geopolitical influence. These movements claimed different sources of authority and fought different sorts of wars - with and against each other, as well as against settler and colonial states. Given the array of influences on liberation movements, explaining the success of any particular one over its competitors is far from straightforward. Sapire has noted a tendency to attribute the ANC's success not to its military action but to 'the capacity to hold together this diverse and scattered movement', alongside its 'ability to project itself at home and abroad as the custodian of South African liberation.'8 Successful military action was certainly more central to the other southern African liberation movements, all of whom had large militaries active on the battlefields of home. Nonetheless, the capacity to contain division and to win battles for recognition and support from hosts and international backers outside the nation was everywhere key.

In addressing these histories, the authors in this collection pursue a number of crosscutting questions. They ask what motivated the men and women who crossed borders to join liberation movements, and how those different motivations were managed and shaped by political and military leaderships, hosting states, military trainers and other authorities. They seek to understand how Cold War influences were acted upon, interpreted and used by African actors, and why some ideas attained greater potency than others. They explore the significance of particular historical moments, strategic locations, personal relations and social and cultural attributes in these processes. In the remainder of this introduction, we spell out the contributions of this collection, beginning with a consideration of methods and sources before turning to a wider set of debates over the transnational histories of liberation movements.

\section{Methods and Sources in Liberation Movement Histories}

The articles in this volume deploy new sources and methods as well as offering new interpretations of familiar materials. Some authors use texts that were previously inaccessible; others return to well used archives, newspapers or memoirs, reading them 'against the grain', or with new questions in mind. Important insights have been gained from African informants. Oral sources are used in some fashion in almost all of the papers and stand at the centre of most of them. Most authors are trained in approaches and methodologies that place the interpretations of African actors at the heart of their work. But among the articles, there is also a productive interplay with authors able to access sources beyond those normally used by Africanists, notably East European archives.

\footnotetext{
${ }^{8}$ Sapire, 'Liberation Movements', p. 276.
} 
The productivity of deploying new sources and methods can be seen in recent scholarship that draws on the voluminous archives of East Germany to explore the global Cold War. ${ }^{9}$ The accessibility and sheer volume of the East German state archives is, however, unusual. Other archives are more parsimonious or difficult to access. The use of the Soviet archives, for example, has been limited to a small number of scholars, Vladimir Shubin key among them. ${ }^{10}$ Gaining access to archives related to liberation movements is also daunting. The expansive South African ANC archives are exceptional, and have been used to explore many aspects of the ANC's struggle history, including exile. ${ }^{11}$ Most liberation movements, however, do not have easily accessible archives or any archives at all. For example, very few scholars have accessed the archives of FRELIMO or ZANU, while ZAPU's records were confiscated by ZANU(PF) in the early 1980s during a period of violent repression. ${ }^{12}$

The absence of these kinds of archives has required creative solutions. In this volume, Timothy Scarnecchia uses the diplomatic records of Western countries to explore the significant roles of African diplomats in shaping the fate of Zimbabwe's liberation movements, while Natalia Telepneva uses recently declassified Eastern Bloc archives including those of Czechoslovakia, Bulgaria and East Germany - to reinterpret official relations with Mozambican liberation movements. Blessing-Miles Tendi's work makes use of a private archive relating to one of ZANU's most influential military commanders and the personal papers of a former government minister. Such private collections are widespread though, as Gerald Mazarire notes, they can be difficult to access and are often in states of perilous neglect. ${ }^{13}$ Where the limits of archives are rapidly reached, our contributors have drawn on other written sources, often hidden in plain sight. This includes the press and the many substantial published collections of documents and oral histories related to liberation struggles, as well as memoirs.

The memoirs of politicians are almost always preoccupied with political projects past and present, but they remain invaluable for exploring the questions at issue here. They may, as in Justin Pearce and Daniel Kaiser's articles, offer a view on the ways in which political elites sought to portray politics and external influences. But memoirs are also written by those who did not come to power or who became critical voices. These reveal

\footnotetext{
${ }^{9}$ For a groundbreaking collection of work, see Q. Slobodian (ed.), Comrades of Color: East Germany in the Cold War World (New York, Berghahn, 2015).

10 See V. Shubin, The Hot 'Cold War': The USSR in Southern Africa (London, Pluto Press, 2008), among his other works.

11 See for example the formidable studies by Hugh Macmillan, The Lusaka Years: The ANC in Exile in Zambia, 1963-1994 (Auckland Park, Jacana Media, 2013), and T. Simpson, Umkhonto we Sizwe: The ANC's Armed Struggle (Cape Town, Penguin Books, 2016).

12 The value of access to 'movement archives' is demonstrated by the work of Josephine NhongoSimbanegavi, one of the few scholars able to use ZANU's archive extensively. See her For Better or Worse? Women and ZANLA in Zimbabwe's Liberation Struggle (Harare, Weaver Press, 2000).

${ }^{13}$ G. Mazarire, 'Rescuing Zimbabwe's "Other" Liberation Archives', in C. Saunders (ed.), Documenting Liberation Struggles in Southern Africa (Uppsala, Nordiska Afrikainstitutet, 2010), pp. 95-106. Personal collections - so-called tin trunk archives - have been lauded among historians of Africa for the windows they open on neglected topics. See K. Barber (ed.), Africa's Hidden Histories: Everyday Literacy and Making the Self (Bloomington, Indiana University Press, 2006).
} 
the visions of people written out of dominant histories and of paths not taken, as in Gerald Mazarire's account of some of the forgotten agents in ZANU's international networks. Mazarire, Tendi, and Hugh Macmillan make use of a relatively recent set of memoirs written by military men that shed light on transnational exchanges and relationships among the militaries of different liberation movements. These accounts are products of a shifting politics of the present, as well as reflecting the advancing age of this cohort. They may come to constitute a new genre, offering a more sceptical and disordered narrative of the making of the nation. ${ }^{14}$ In this volume, we offer two personal reflections by former active agents in the making of transnational connections - Vladimir Shubin and Dumiso Dabengwa, discussed further below.

Memoirs share some commonalities with oral histories - including the workings of memory and the mediation of political and other agendas. But interviews can range more widely without the winnowing effects of writing and publishing. Oral history has of course been a key methodology in the writing of African history since the 1960s, cast not least as antidote to the state-dominated view of the colonial archive. ${ }^{15}$ Oral histories also offer an important contrast to the picture of Africans that has emerged from East European state archives. ${ }^{16}$ In this collection, they make a substantial contribution: oral histories are central to our exploration of African points of view on transnational movements, hosts, training and cold war ideologies. Interviewing on these topics is, however, far from straightforward. Participants in liberation struggles may feel bound by past ethics of secrecy; their histories may be inconvenient to the present. Such strictures also apply to those who fought against liberation movements. For all interviewees, political narratives are constrained and shaped by the overweening influence of nationalist accounts of liberation. Informants may in addition simply be hard to locate. Interviewing political and military figures often requires a long-term investment in building relationships of trust and in overcoming the prosaic challenges of finding people, alongside the difficult work of tracing the mediating influences of context, power, and politics on individual accounts.

Many authors in this volume have built such relations of trust over many years. Tendi's and Mazarire's interviews with ZANU members delve deep for this reason, broaching

\footnotetext{
${ }^{14}$ On these genres of writing see, for example, S. Nuttall, "Telling "free" stories? Memory and democracy in South African autobiography since 1994', in S. Nuttall and C. Coetzee (eds), Negotiating the Past: The Making of Memory in South Africa (Oxford, Oxford University Press, 1998).

15 Offering up an African 'voice' in any straightforward way is not, however, the goal of more recent uses of oral histories. See L. White, S. F. Miescher, and D. W. Cohen (eds), African Words, African Voices: Critical Practices in Oral History (Bloomington, Indiana University Press, 2001).

${ }^{16}$ It is instructive to place the work of scholars who have delved deep into the GDR archives alongside Marcia Schenk's oral histories of African actors in the GDR. The stories they tell share common ground, but they are also profoundly different in what they reveal about the ways in which the history of solidarity, ideology, discipline, and social life was recorded, interpreted and remembered. Compare, e.g., S. Pugach, 'African Students and the Politics of Race and Gender in the German Democratic Republic', in Slobodian, Comrades of Color, pp. 131-56, and M. Schenck, 'Eastalgia in Mozambique: Memories and Dreams of Mozambican Contract Laborers to the German Democratic Republic', paper presented to the African Studies Seminar, St Antony's College, Oxford, 19 May 2016. Schenck notes that her findings contrast sharply with a post-unification German literature that draws on archival sources.
} 
divisive topics and silenced views. Their work has also been shaped by the breaches created by the deep ructions within ZANU(PF) of recent years. Munguambe's interviews with FRELIMO leaders and soldiers builds on her work with FRELIMO's Antigos Combatentes. She and Kaiser undertook their research in a period in which the glories of FRELIMO's revolution had been recast in a 'post-socialist' Mozambique, opening out new possibilities for narrating the past. ${ }^{17}$ Christian Williams and Pearce bring to bear the insights of long-term historical ethnographies, work that allows them to go beyond African elite views on the meaning and legacies of Cold War ideas. ${ }^{18}$ Jocelyn Alexander and JoAnn McGregor draw on several decades of work with members of ZAPU and its armed wing. They were able to identify and interview members who had trained in the Soviet Union and to place their stories against the background of an established set of ZAPU narratives of war. Lennart Bolliger's ground-breaking work among veterans of SWATF and Koevoet - groups disparaged as sellouts in a dominant nationalist narrative in Namibia - builds on relationships he made with their representative organisations in a moment in which they were actively demanding recognition.

The range of sources and methodologies deployed in this collection do not exhaust the possibilities of research on the transnational histories of liberation movements, but they allow us to pose new questions and offer new insights in three key areas: first, African uses of the Cold War and engagement with global ideologies; second, African diplomacy, broadly construed; and third, the interactions across Southern Africa between and among mobile soldiers and host states and societies.

\section{African Uses of the Cold War}

One effect of the uses of new sources for scholarship on Southern African liberation wars has been to open up a conversation with literature on the global Cold War. In the latter, questions over the role of ideology have often been central. Odd Arne Westad, for example, stresses the importance of contested ideas and visions of modernization, development and 'stateness'. ${ }^{19}$ Scholarship on Eastern bloc solidarity has begun to offer sophisticated accounts of varieties of socialism across the 'Second World', paying close attention not only to differences among state ideologies and official practices, but also to the motivations, initiatives and sentiments of solidarity actors. This work has unearthed mutable and diverse understandings and uses of socialist and capitalist ideologies. $^{20}$

\footnotetext{
${ }^{17}$ M. A. Pitcher, 'Forgetting from Above and Memory from Below: Strategies of Legitimation and Struggle in Postsocialist Mozambique', Africa, 76, 1 (2006), pp. 88-112.

18 See Williams, National Liberation; J. Pearce, Political Identity and Conflict in Central Angola 1975-2002 (Cambridge, Cambridge University Press, 2015).

${ }^{19}$ Westad, The Global Cold War, p. 4. See also J. Friedman, Shadow Cold War: The Sino-Soviet Competition for the Third World (Chapel Hill, University of North Carolina Press, 2002), p. 20.

${ }^{20}$ Q. Slobodian, 'Introduction', in Slobodian, Comrades of Color, p. 7, and see contributions to this collection more widely.
} 
The authors in this cluster - Pearce, Kaiser and Alexander and McGregor - echo these interests and concerns. They seek to shed new light on the question of ideology and its impact on Southern African liberation movements by drawing on the varied categories and understandings of a range of African actors who have been inadequately included in these debates, or who are entirely absent. These perspectives - particularly those of non-elite actors - have left scant if any trace in official archives. Bringing such views to light addresses a persistent tendency in Cold War scholarship to bolster a view of Soviet or American manipulation of Third World clients. ${ }^{21}$ All the authors find that relations with Cold War sponsors were central to the fates of liberation movements (and of factions within them), but that all were also built on complex and contradictory bases that ranged beyond ideology, and that each movement forged its own claims to authority through locally rooted cultural and historical narratives.

Justin Pearce's article concerns Angola, a country in which scholars have long asserted the importance of ideologically-driven Cold War intervention, but have not connected that assertion to an analysis of local level politics. Pearce asks how foreign support for the MPLA and UNITA shaped their mobilization within Angola. Though Cold War sponsors deeply polarized rival movements, he stresses how slight was the impact of Cold War ideology on ordinary people's political affiliations and views. Rather, both movements used the power derived from external support to appeal to their Angolan constituencies based on local, historically formed ideas of authority, notably a sense of 'stateness'. There was no straightforward connection between the presence of foreign supporters, the ideas of elite Angolan actors, the representations of both of these in popular discourse in different parts of the country, and the ways in which adherence to one or other party worked on the ground. The ideological binaries that shaped the Cold War were, Pearce argues, 'refracted through a prism of Angolan contingencies, identities and loyalties'. Pearce concludes that external intervention could both reinforce and undermine the legitimacy of Angolan political movements, and that for many Angolans untouched by direct mobilisation it simply fed a 'suspicion of all things political.'

Key figures in Mozambique's dominant liberation movement, FRELIMO, are the focus of Kaiser's article. His is not a view from the grassroots but seeks instead to explore the ways in which FRELIMO elites were socialised in and made use of transnational networks. He does not find a story of ideological imposition from the Eastern Bloc, rather arguing that particular actors within FRELIMO developed the necessary social and cultural 'capital' - rooted in their access to education in Mozambique and then in universities abroad - to monopolise relations with international supporters. Such

\footnotetext{
${ }^{21}$ David Engerman, for example, argues that the Eastern Bloc archives allow the study of 'the USSR in transnational context' - i.e. they allow for more sophisticated understandings of Soviet (and other) engagements with the Second World, rather than shifting the lens to, as in this volume, African theatres of intervention as seen through Southern African actors' eyes. D. Engerman 'The Second World's Third World', Kritika: Explorations in Russian and Eurasian History, 12, 1 (2011), pp. 183-211. Similar points are made regarding the Middle East. E.g., see N. J. Citino, 'Between Regional and Global Narratives', International Journal of Middle East Studies, 43, 2 (2011), p. 314.
} 
actors used the privileged access they enjoyed to transnational networks to accumulate legitimacy and power - via resources, money, guns, and recognition - and thereby to win power struggles within the national movement. The boundary crossing Kaiser finds in student groups, universities, and a diverse range of international organisations located in both the East and West significantly shaped the direction of the Mozambican 'national' struggle. FRELIMO elites produced a robust imagination of a unified Mozambican nation, an anti-racist policy, and a socialist ideology - ideas that were certainly shaped by Cold War influences, but that were not contained by them. Like Pearce, Kaiser finds one outcome of these transnational processes to be a negative effect on postcolonial politics as the country's powerful elite proffered a vision of revolution and development at odds with those of key constituencies.

Alexander and McGregor's article on the Soviet-backed Zimbabwean liberation movement, ZAPU, finds that African actors did not put ideology at the centre of their experience of the USSR, though they were indelibly influenced by that experience. Their focus on African soldiers' lives in the USSR is unusual in a literature dominated by the stories of African students. Based on interviews with members of ZAPU who trained in military intelligence in the Soviet Union in the 1960s and 1970s, they show how these African trainees stressed their own attributes as educated men and sophisticated political thinkers as a basis for their influence on, and good relations with, Soviet trainers. Their responses to the ideas of their Soviet interlocutors - technical as well as ideological - were most powerfully shaped by their assessment of the needs and demands of Rhodesia, both in terms of the particular terrain and strategy of the war, and in terms of their plans for state-building and development in the future. ZAPU cadres stressed that it was not formal teaching that most strongly influenced their views, but the understandings they gained of Soviet history and their experiences of 'living socialism'. The former inspired awe in the face of almost unimaginable sacrifice during the 'Great Patriotic War' (World War II) while the latter appealed for the alternative it offered to Rhodesian discrimination and hierarchy. These men also recalled that their assessments of Soviet ideas took place in a crowded field: many had experience of other socialisms in Cuba, China, Vietnam, and a host of African countries.

This group of articles provides a powerful statement on the diverse rationales and utilities of transnational engagements and exchanges from the viewpoint of liberation movement actors and their African constituencies. These external relations shaped the views and aspirations of these movements as well as the paths to victory of factions within them, but they were far from reducible to a story of ideological imposition or manipulation from abroad. The focus thus far has been primarily on African prisms for understanding relations with Eastern Bloc and Soviet socialisms and relations, but it has already become apparent that a multiplicity of other external relations were centrally important to liberation movements' trajectories and internal politics, as well as to their international diplomacy. 


\section{African Diplomacy and International Connections}

The diplomacy undertaken by both African states and liberation movements was crucial to maintaining flows of weapons, material aid, and humanitarian support as well as shaping the terms of peace and political transition, as has long been recognized in the study of international relations and in specifically Southern African literatures. It is a truism that independence struggles were fought not only on the battlefield but around the negotiating table and within international institutions. Here we suggest additional dimensions to understanding African diplomacy on all sides. New sources allow a consideration of wider networks of African actors - students and lawyers prominent among them - who represented liberation movements formally and informally across the globe. They also allow a reassessment of the considerable influence of state actors usually granted a marginal role, notably the middle level bureaucrats and diplomatic agents of African and Eastern Bloc states that stood on the sidelines of great power rivalries. This reassessment adds to a wider literature that has emphasized the at times decisive role of actors beyond the superpowers in Cold War histories. ${ }^{22}$ Exploring who mediated, with what means and to what ends, reveals a host of surprising relations and agendas that did not follow neat ideological or strategic divisions, often in fact thriving in their interstices and contradictions.

Natalia Telepneva's article focuses on the Eastern Bloc interlocutors with FRELIMO. She retraces the process through which an alliance between the USSR and FRELIMO emerged, arguing that this was neither an imposition nor a product solely of African agency, but rather that it should be understood in the light of the roles of key intermediary figures. Specifically, she focuses on mid-level Eastern Bloc bureaucrats, survivors of World War II and in some cases brutal inter-war purges, who knew little of Africa but whose views were powerfully shaped by the international communist movement and a strong commitment to ending colonial exploitation. They were drawn to African political actors able to portray themselves as 'progressive', a point that reinforces Kaiser's argument regarding the sorts of social and cultural capital that allowed particular liberation movement representatives to thrive in this milieu. She argues that the personal relationships between mid-level Eastern Bloc officials and Marcelino Dos Santos in particular helped FRELIMO to triumph over rival movements in the pursuit of recognition and resources, an emphasis that is echoed more broadly in the work of both Shubin and Westad.

Gerald Mazarire's article revisits ZANU's external relations. He reveals the sheer diversity of international connections that is missed both in a narrow focus on major powers and in the streamlined narratives of victors. The article emphasizes the politics of the OAU and key participants such as Nigeria. He explores the complexity of relations

\footnotetext{
${ }^{22}$ Important work in this regard can be found in P. Gleijeses, Conflicting Missions: Havana, Washington and Africa, 1959-1976 (Chapel Hill, University of North Carolina Press, 2002); T. Smith, 'New Bottles for New Wine: A Pericentric Framework for the Study of the Cold War', Diplomatic History, 24, 4 (2000); and Friedman, Shadow Cold War.
} 
between individual Frontline state leaders (Tanzania, Mozambique and Zambia of course, but also Malawi) and other African states. He notes how these relations shaped the opportunities and constraints of cohorts of ZANU students, lawyers and only later formal diplomats who sought recognition, funds and guidance. These varied actors underline the importance of broadening the category of 'diplomat' as well as the sheer mobility of people, ideas and resources. Mazarire shows how a movement like ZANU, whose external existence was constantly threatened by its perilous lack of 'authenticity' (granted to its rival ZAPU), was nonetheless able to survive by playing on the contradictions among the many institutions, organisations, solidarity groups, states and individuals who were involved in supporting liberation movements. The fissures in which ZANU's diverse band of representatives were able to insert itself and gain support played off a bewildering array of international disputes and alliances well beyond its control, from the complicated machinations of Ethiopian and Libyan politics, to the more familiar Sino-Soviet rivalries.

Tim Scarnecchia's exploration of African diplomatic representation of the Zimbabwean liberation movements reinforces Telepneva's emphasis on the significance of personal ties and actors beyond the superpowers. It also confirms Mazarire's fissured picture of international support and solidarity, and the odd bedfellows it at times produced. Scarnecchia dismantles a neat mapping of diplomatic alliances onto national interests. These alliances were more fungible than such a mapping would indicate; the interests at stake were shifting and particular, sometimes accidental or opportunistic, and subject to divergent interpretation. Using diplomatic records, Scarnecchia demonstrates the important role that Frontline and Nigerian foreign ministers and diplomats played in interpreting liberation movements to the superpowers. This role gave these weaker, poorer states an influential intermediary position from which they were able to play on the Cold War worries of the superpowers, as well as to attempt to discipline the fractious liberation movements themselves. As Scarnecchia argues, these transnational relations had real implications for the prosecution of the Zimbabwean struggle, its negotiated end - and its violent aftermath.

These explorations of diplomacy begin to give us a sense of the importance of specifically African interactions between liberation movements and host states. But such regional interactions and connections went well beyond the diplomatic sphere, as the next section explores.

\section{Hosts, Allies and Enemies on the African Frontline}

The literature on the regional dynamics of Southern Africa's liberation wars has only begun to touch on the complex histories of cross border movements, relationships and interactions. At some junctures, host states clearly wielded immense power over 'exiled' liberation movements, most visibly at moments of division and mutiny when revolts were put down, rebels imprisoned or movements expelled. But these relations were 
more often negotiated amidst shifting balances of power, and dealt in the subtler currencies of solidarity, training, cultural exchange, and ideas. Such interactions are only beginning to be explored, and are dominated by studies of the ANC. Even less well understood are the implications - and legacies - of liberation movements' transnational interactions with one another. The legacies of liberation wars are equally important for the state forces that fought liberation movements, themselves also transnationally constituted, though this is a topic on which scholarship is almost entirely silent. The articles in this section seek to deepen our understandings of regional dynamics in all these respects. They trace a fascinating set of negotiations and conflicts over ideas, institutions, identities, and power that reached across borders in the past and that continue - for good and ill - to reach across borders in the present.

We begin with Williams' exploration of education during SWAPO's exile in Tanzania. Williams argues that a focus on nationalism is inadequate to understanding the motives of early SWAPO recruits: for many, access to education was central among their goals. In exile, education was a source of dispute among cadres, alternately venerated and denounced by differently positioned (and educated) generations within the movement. Williams' analysis is particularly insightful in shedding light on the ways in which both transnational institutions of learning outside the camps, and sites of education in the camps themselves, served as arenas for reinterpreting the meanings of Cold War politics. These re-appropriations were a means of debating the purposes of SWAPO; they were equally linked to Cold War powers' attempts to exercise influence on SWAPO. Williams' contribution, alongside those in our first group of articles, leaves us with a finer-grained understanding of how liberation movements engaged global ideologies and made use of them in internal battles.

Tendi's paper on the 1974/75 Nhari mutiny in ZANLA has resonances with Williams' article. As Tendi shows, overlapping educational and generational differences were central to ZANU's conflicts in exile too. However, while Williams underlines the influential interventions of host states in determining who triumphed at moments of upheaval, Tendi suggests that the ZANLA leadership succeeded in violently suppressing the Nhari mutiny in the face of alleged collusion between the Zambian government and the mutineers. He stresses the significance of transnational influences on the mutiny in several respects. First, he shows that the mutineers timed their revolt to take advantage of the military leadership's absence on diplomatic missions abroad. Second, Tendi argues that the revolt was motivated most powerfully by deteriorating conditions across the border, on the warfront in Rhodesia. In doing so, he offers a new interpretation of the mutiny, as well as calling attention to the impact of battlefield conditions on camp life. Third, both the mutiny and its repression made use of multiple border crossings: the mutineers plotted on Mozambican soil, initiated the revolt in Rhodesia, and then advanced to Zambia to take over ZANLA's camps there. The ZANLA leadership retook control of the Zambian camps by importing a crack force from a training camp in Tanzania; some of the mutiny's leaders fled to Mozambique where they were tracked down with FRELIMO's assistance. Both the challenge and the resolution of 
the Nhari mutiny were thus formed in the opportunities, grievances and resources made in and by border crossing.

Clinarete Munguambe's article also concerns ZANU abroad, but from a different viewpoint. She scrutinises ZANU's cooperation with FRELIMO from the perspectives of their Mozambican hosts, views that are barely explored in the literature. Munguambe uses interviews with FRELIMO leaders and soldiers as well as Mozambicans resident on the Rhodesian border to tell a story about the evolution of FRELIMO-ZANU relations from a 'frosty' start, to closer collaboration built on a flexible solidarity and on negotiation, a story with echoes in the accounts of Scarnecchia and Mazarire. FRELIMO at first supported ZANU's rival, ZAPU, a fellow 'authentic' liberation movement with which FRELIMO cadres had made common cause in the camps of Tanzania. But when ZAPU was paralysed by internal division in 1971, ZANU attracted FRELIMO support owing to its ability and willingness to fight. When Frelimo came to power in 1975, it asserted a radical commitment to solidarity with struggles for national liberation. Munguambe shows that this took the form not only of substantial rear bases for ZANU and support for refugees but also transnational military intervention. As Rhodesian counterinsurgency operations escalated, 'hosting ZANLA and defending Mozambique's territory and sovereignty became one and the same thing for FRELIMO.' Munguambe suggests that, by 1979, over 600 FRELIMO soldiers were fighting inside Rhodesia. These soldiers were chosen for their war experience and knowledge of Zimbabwean languages, building on the long history of border crossing and shared identities with Rhodesia. Munguambe also notes the role of this porous border in the dynamics of popular support. People living along the borders supported refugees and guerrillas in a host of ways, in part because of FRELIMO's revolutionary dictums, but also owing to shared cultural, linguistic, and sometimes kinship, ties. All was not, however, amiable in these relations: Munguambe notes tensions among fighters in Rhodesia over tactics and relations with women, and between FRELIMO and ZANU leaders over failed efforts to achieve unity with ZAPU. Ultimately, FRELIMO used its power as host to insist on a negotiated end to a war that had grown too costly.

Munguambe hints at some of the influences FRELIMO may have had on ZANU in ideological terms, alongside the effects of its transnational military collaborations. Such influences across liberation movements are clearly important, but are little researched and difficult to pin down. Hugh Macmillan's paper highlights both the importance and slipperiness of these links in a study of the ANC's military alliance with ZAPU. Most work on this topic has focused on the joint campaigns of the late 1960s. Macmillan draws our attention to the collaborations of a decade later, just before the war's end, when ZIPRA was at the height of its power. This episode has gone little remarked: it had no place in ZANU(PF)'s victor's history. Macmillan shows that, in the late 1970s, the ANC's armed wing, MK, shared camps with ZIPRA in Zambia and Angola, and had, in 1979, infiltrated at least 100 MK cadres into Rhodesia alongside ZIPRA. The legacy of this alliance for the 1980s was an extremely rocky relationship between the ANC and 
ZANU(PF), with reverberations into the present, while ZAPU continued to aid the ANC amidst its own severe repression.

The close relations forged over decades between the ANC and ZAPU did not, however, mean MK cadres appreciated ZIPRA's political and cultural influence. Drawing on MK memoirs and accounts, Macmillan shows that these cadres considered ZIPRA training to be anti-intellectual, overly focused on physical feats, and at times racist and harshly coercive. They depicted the toyi-toyi, a training march accompanied by chants and songs, as a symbol of this apolitical militarism, and traced its deleterious spread from Zambia into MK camps in Angola. Macmillan concludes by tracing MK cadres' introduction of the toyi-toyi to South African townships in the mid-1980s, where it became an iconic means of performing resistance, and beyond that, to the politics of Julius Malema and to current student protests. In this circuitous fashion, the cultural and political exchanges of the war years, he argues, have continued to shape 'the way South Africans see their past - and create their present and future.' We might add a coda to this account: ZIPRA cadres hold that the toyi-toyi originated not with them but in the training drills learned in early 1960s Algeria. The term toyi-toyi and the chants that originally went with it were said to be in Arabic, offering an extraordinary tale of cultural and political mobility and appropriation across the continent.

Lennart Bolliger's article offers a fitting conclusion to this section. He is concerned with the legacies of transnational wars not for members of liberation movements but for their opponents, in this instance black Namibians recruited into two arms of the South African security forces, SWATF and Koevoet (a police counterinsurgency unit). This is an unexplored topic generally in academic work: as Bolliger writes, 'From World War II to date, no study has focused on the (post-liberation war) politics and narratives of African members of any of the southern African settler and colonial security forces.' Such stories have fit with neither victor's histories nor nationalist narratives. After Namibian independence, black members of Apartheid South Africa's forces were labelled as traitors by SWAPO. In post-liberation South Africa, they were regarded as, at best, on the wrong side of history. Bolliger finds that their wartime identities nonetheless proved extraordinarily durable. Black veterans constituted two distinct organisations and fashioned narratives that allowed them to launch political and legal claims to national belonging, veteran status and citizenship in both Namibia and South Africa. These fascinating stories offer a glimpse into the messy, ongoing legacies of transnational wars for all those involved, as well as raising wider questions about the resilience of military identities across the region and their implications for the making of nations and states.

\section{Making and Remembering Transnational Histories}


Our last two articles touch on many of the themes that cut across the collection as a whole. As we have noted, and as many of our authors have demonstrated, the patchy accessibility or lack of archival sources has placed a premium on the oral histories and writings of participants in Southern Africa's liberation struggles. Individual reflections are not only important for the making of personal meaning, but also for the ways they may be used as evidence and as instances of memory and myth-making. It is thus fitting for this special issue to end with the reflections of two participants in the making of transnational relationships, Dumiso Dabengwa and Vladimir Shubin.

Dabengwa and Shubin write from the viewpoints, respectively, of the former chief of ZAPU's intelligence service, and of a key actor in Soviet support for that movement, the one-time Secretary of the Soviet Afro-Asian Solidarity Committee. The two men knew one another, and interacted in the course of the struggle. They entwine their own life histories with discussion of ZAPU's war effort and the USSR's assistance thereto. Both also write from a position in which the heroic acts of the struggle sit awkwardly with a post-independence history of marginalisation. As we have seen, ZAPU was violently repressed after 1980, until it was subsumed in ZANU(PF) in 1987. The Soviet Union, like the ANC, paid dearly for its alliance with ZAPU - as Shubin notes, the USSR had to wait ten months for Zimbabwe to establish diplomatic relations, and it only did so on condition that the Soviets end all contact with ZAPU. Both men also write at a moment in which the whole range of conditions that had enabled the solidarities they had built with each other no longer exist.

These accounts are important in reminding us of the excitement and novelty inherent in building transnational relationships - as well as their sacrifices and sometimes stuttering progress. Dabengwa's account starts with a young man's view on ZAPU's early sabotage campaigns. He recounts tales of little known transnational connections and flows of munitions from the Congo to Rhodesia, via Lusaka, in the 1960s. He takes us to Moscow, where he emphasises the technical skills he gained as well as the political debates in which he engaged. Dabengwa's account of his return to Lusaka underlines the difficulties liberation movements faced in managing the varied, sometimes incompatible, influences of supporters from across the globe. Some 100 ZAPU men who had undergone training in the USSR, China, North Korea, Cuba and Egypt reconvened in Lusaka at the end of 1964, and spent two weeks 'engaged in daily, highly charged debates' over how to prosecute the armed struggle. These debates ranged over tactics, ideology, and historical example, as well as ideas about bravery and cowardice. They offer a fascinating example of the effects of a 'decentred' Cold War, reflecting themes developed by many of the authors in this volume.

Shubin's piece affirms the significance of bureaucratic and personal connections between liberation movements and their external supporters in facilitating the flow of material aid and diplomatic work, as also emphasised by many of our authors. Shubin's close personal allegiance to a number of ZAPU figures, built over many years, is clear, as is the great frustration he felt when ZAPU's struggle was paralysed by division or 
slowed by negotiation. He also rues, with evident hindsight, the extent to which loyalty to ZAPU meant that opportunities for building relations with the eventually victorious ZANU were not taken up. Shubin's account is in addition important for addressing a crucial aspect of the USSR's support for ZAPU during the later stages of the war, when Soviet and Cuban instructors provided training to over 8,000 ZIPRA cadres in Angola, a story that, despite its significance - and the severe hardships endured by all those involved - is barely touched upon in Zimbabwe's struggle histories. As both Dabengwa and Shubin emphasise, the relationship between the USSR and ZAPU went well beyond the military - there were substantial educational links, and both note the importance of Soviet diplomatic and legal support to ZAPU during the Lancaster House negotiations.

These reflections thus allow us to bring together many of the contributions of this volume - to understandings of African appropriations, adaptations and rejections of global ideologies, to debates over African diplomacy in the vast and shifting web of international support, to the complexities of the relationships that shaped exile within Southern Africa, and to our grasp of the convoluted political and cultural legacies of both transnational insurgency and counterinsurgency. Exploring these themes using new sources, and with a focus on the Zimbabwean, Mozambican, Namibian and Angolan liberation movements, offers a host of insights that build on the rich literatures on the ANC in exile and the global Cold War. It also underlines just how much work remains to be done on the transnational circulations, interactions and experiences that so powerfully shaped southern Africa's liberation struggles and their legacies for the region. 